\title{
An Integrated Model for the Study of Teacher Motivation
}

\author{
Saul Neves de Jesus* \\ Departamento de Psicologia, Faculdade de Ciências Humanas e Sociais, \\ Universidade do Algarve, Portugal \\ Willy Lens \\ Department of Psychology, University of Leuven, Belgium
}

\begin{abstract}
Des recherches récentes ont montré que les enseignants souffraient plus que d'autres groupes professionnels d'un manque de motivation au travail. Une compréhension globale de la motivation des enseignants exige un modèle adéquat. L'objectif principal de cette recherche était de proposer et de mettre à l'épreuve un modèle de la motivation des enseignants qui intégre des concepts de plusieurs théories cognitivo-motivationelles. Le modèle intégré s'appuie sur la schéma expectation-valence et celui de l'incapacité acquise, mais surmonte quelques-unes de leurs imperfections. L'échantillon était composé de 272 enseignants des écoles élémentaires et secondaires du Portugal. Ils ont répondu à une série d'inventaires destinés à mesurer leurs expectations de contrôle, de succès et d'efficacité, leurs attributions, leur motivation intrinsèque, la valence de leurs buts perçus et comment tout ceci interagit pout agir sur l'engagement professionnel (la variable exogène du modèle). Les analyses des coefficients de pistes et de la variance des variables endogènes valident le modèle intégré proposé ici et suggèrent des stratégies de formation pour accroître la motivation des enseignants.
\end{abstract}

Recent studies show that teachers suffer more than other professional groups from the occupational lack of motivation. A global understanding of teacher motivation requires an adequate framework for its study. The main goal of the current research was to propose and test a model of teacher motivation that integrates constructs from several cognitive-motivational theories. This integrative model starts from the perspectives of Expectancy-Value and Learned Helplessness but overcomes some of the limitations of each. The participants were 272 elementary and secondary teachers in Portugal. They responded to

* Address for correspondence: Saul Neves de Jesus, Departamento de Psicologia, Faculdade de Ciências Humanas e Sociais, Universidade do Algarve, 8000 Faro, Portugal. Tel: +351-289800914; Fax: +351-289-818560; Email: snjesus@ualg.pt

This research was supported by the Instituto de Psicologia Cognitiva, Desenvolvimento Vocacional e Social, University of Coimbra, Portugal.

(C) International Association for Applied Psychology, 2005. Published by Blackwell Publishing, 9600 Garsington Road, Oxford OX4 2DQ, UK and 350 Main Street, Malden, MA 02148, USA. 
a series of inventories designed to measure their expectancies of control, success and efficacy, attributions, intrinsic motivation and perceived goal value levels, and how these interact to influence professional engagement (the model's exogenous variable). Analyses of path coefficients and the variance of endogenous variables support the proposed integrated model and suggest strategies for teacher education that may increase teacher motivation.

\section{INTRODUCTION}

Teacher motivation is an important concern for educational leaders and managers because teacher motivation has an important effect on student motivation. A common teacher's complaint is the difficulty of keeping students motivated to learn in the classroom: How much more difficult is it if the teachers themselves are not motivated?

Teacher motivation is also important for the advance of educational reforms. First, motivated teachers are more likely to work for educational reform and progressive legislation. Second - and perhaps more importantlyit is the motivated teacher who guarantees the implementation of reforms originating at the policy-making level.

Finally, teacher motivation is important for the satisfaction and fulfilment of teachers themselves. Beyond issues of personal well-being, such feelings of satisfaction are consistently associated with lower levels of organisational absenteeism and turnover (Jesus \& Conboy, 2001; Mowday, Koberg, \& McArthur, 1984; Porter \& Steers, 1973).

In spite of the fundamental importance attributed to teacher motivation, it is a common research finding that teachers show lower levels of motivation and higher levels of stress than other professional groups (Alvarez et al., 1993; Esteve, 1992; Kyriacou, 1987; Lens \& Jesus, 1999; Pithers \& Fogarty, 1995; Prick, 1989). In Portugal, for instance, it is estimated that fewer than $50 \%$ of teachers desire to continue in the teaching profession. The majority would prefer to change their professional activity (Jesus, 1996).

When the general importance of having motivated teachers is contrasted with the general lack of teacher motivation, a gross disparity is evident: In short, while teacher motivation is fundamental to the teaching/learning process, many teachers are not highly motivated.

Although many studies have been reported on the topic of teacher motivation, a more general integrative theoretical structure for its study remains elusive. The development of such a framework would be useful for a number of reasons. It would promote the study of the phenomenon of teacher lack of motivation in all its diverse manifestations and aetiologies. It would support wider, but more coherent perspectives on the problem and, perhaps most importantly, it would encourage the use of a restricted terminology so that researchers use the same terms to describe the same phenomena. As Esteve (1992, p. 30) put it, what is required is "a comprehensive

(C) International Association for Applied Psychology, 2005.
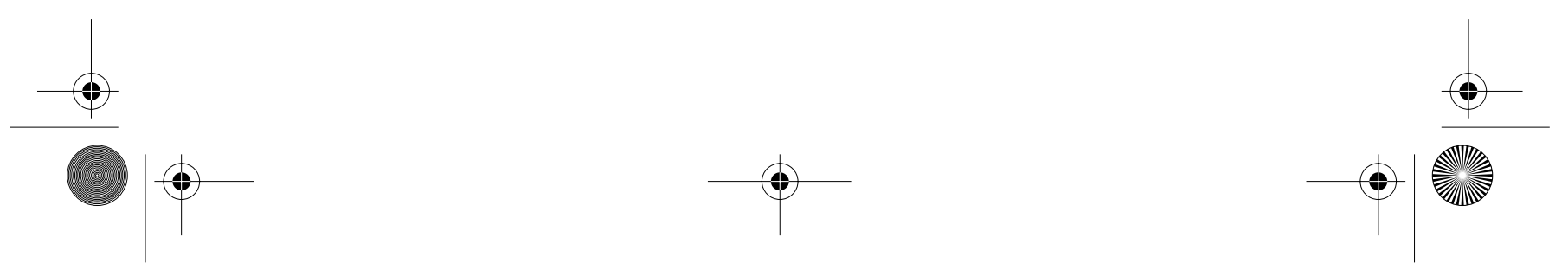
vision of what is actually taking place in the practice of teaching". The consequences for failing to develop an adequate framework are severe. First, isolated studies that do not benefit from the results of previous studies will multiply. Second, proposed intervention strategies will continue to be limited to hastily contrived suggestions that may be deficient or incomplete.

The integration of various complementary theories for the explanation of the same phenomena is generally considered an appropriate strategy for scientific advance as well as for the development of more encompassing prevention and intervention proposals. A theoretical integration should seek to harmonise the contributions from various relevant, comparable and comprehensive theories. If competing theories make the same basic epistemological assumptions and differ primarily due to the specialisation and focus of their authors, it is often best to undertake a coherent unification of those theories, in order to be better able to explain the complexity of the phenomenon under study. An original theoretical synthesis, or a more global framework for the solution of practical problems, may result from such an integration (Barros, Barros, \& Neto, 1993; Ford 1992; Lens \& Decruyenaere, 1991; Palenzuela, 1988; Weiner, 1992). The theory-integration approach is particularly advantageous and justified in the area of motivational psychology. As contemporary motivational theories have become more specific and precise, they have also become more restricted in their range. As Ford (1992, p. 15) indicated, "the practical utility of any theory of motivation will be largely dependent on how well the objectives of conceptual clarity and theoretical integration are attained".

Many theories tend to overvalue one concept or variable. When this occurs, an integration of theories becomes especially profitable for a better understanding of the complexity of human behaviour. Such is the case for the constellation of cognitive-motivational variables used in research of the phenomenon of teacher motivation. The analysis of the partial explanatory power of each of these "overvalued" variables may still be relevant, but the global understanding of teacher motivational problems requires an integration of theories in order to harmonise the specificity and the complementary nature of the theories.

The objective of this study, therefore, is to study teacher motivation through the lenses of different cognitive-motivational theories in order to elaborate a model capable of explaining functional relations that exist between cognitive-motivational variables and one indicator of teacher lack of motivation, that is, the lack of professional engagement.

\section{AN INTEGRATED MODEL OF MOTIVATION}

The learned helplessness/attribution reformulation (Abramson, Seligman, \& Teasdale, 1978; Miller \& Norman, 1979) analyses situations in which the

(C) International Association for Applied Psychology, 2005.
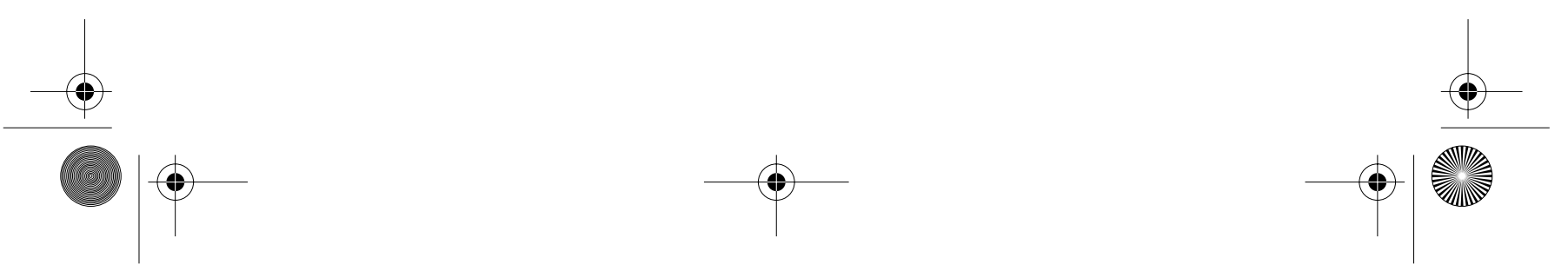


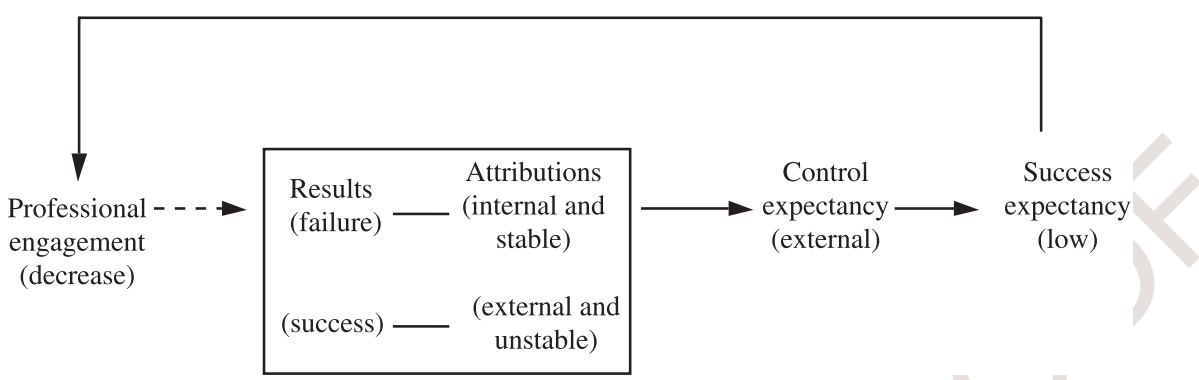

FIGURE 1 Teacher motivation predicted by the learned helplessness model

individual, having experienced failure, constructs causal explanations to account for that failure. Individuals who construct internal, stable and general attributions in order to explain their negative results have a greater tendency to show symptoms of depression than those whose failure attributions are external, unstable or specific. This theory has also been applied to the study of teacher stress (Martínez-Abascal, 1991).

The learned helplessness model assumes that the stressed teacher was initially motivated for success but was exposed to successive, uncontrollable failures. If these failures were attributed to internal and stable factors and the teacher "learns" that results cannot be controlled, regardless of personal actions taken, a general expectancy of external control (Rotter, 1990) develops as the individual teacher concludes that failure is dependent on factors beyond her personal control (as almost $80 \%$ of the teachers in this study are female, she or her are used and not he or his). A similar situation can occur if the teacher constructs external, unstable and uncontrollable attributes to explain professional successes.

The belief in the uncontrollability of results leads the teacher to develop an expectancy of helplessness and hopelessness or a low expectancy of success. The helpless teacher expects the same (negative or low) results whether she tries hard or whether she tries little, and this forms the basis for her reduced effort which makes further professional failure more likely (see Figure 1). Evidence for the direct influence of success expectancy on professional behaviour has been provided by Jesus (1996).

The process described in Figure 1 can be exemplified by the experience of a hypothetical teacher who has just started professional practice. She prepares classes carefully and enthusiastically, and works diligently in order to improve and diversify her teaching. In spite of all her efforts, she consistently perceives disinterest and low levels of performance on the part of her students. She experiences this as a failure and may eventually attribute students' lack of motivation to internal and stable personal characteristics of herself. She

(C) International Association for Applied Psychology, 2005.
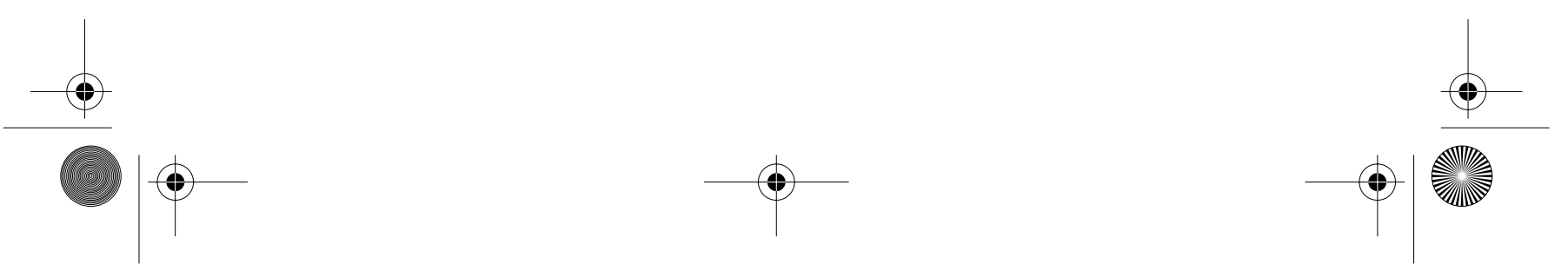
may begin to think, for instance, "I lack the skill, the vocation, to be a good teacher", and she may develop a generalised expectancy that student motivation depends on interpersonal qualities that she does not possess. The teacher "learns" that gaining the attention and maintaining the interest of her students is beyond her personal control, and she begins to manifest her feelings of helplessness, discouragement, and lack of motivation. The generalised expectancy develops that, with or without her effort, student interest in the subject matter will be low. As a consequence of these expectancies, the teacher develops symptoms of professional stress and a tendency for professional disengagement, adopting, as Esteve (1992) termed it, a posture of routine and inhibition.

The learned helplessness model does not recognise, however, that a teacher can have low success expectancy without manifesting lack of motivation or burnout. Sometimes the teacher merely develops indifference toward the source of stress. According to Esteve (1992), the key to understanding the stressed teacher is the teacher's professional engagement. Note that the teacher who exhibits the least engagement may become, paradoxically, the one at least risk of developing stress. This observation ties in closely with the distinction sometimes made between teachers with "burnout"- those who persist in their efforts in spite of their dissatisfaction-and teachers described as "wornout" - those who reduce professional effort due to their dissatisfaction (Stephenson, 1990).

The motivational discrepancy model may provide additional clues for the explanation of teacher lack of motivation and may overcome limitations of the learned helplessness model. This model starts from the empirically supported assumption that situational antecedents to teacher lack of motivation include settings in which highly valued goals are coupled with a low expectancy of goal attainment (Jesus, 1995).

The basis for professional achievement, according to this perspective, is the perceived value of goals. This being the case, a teacher will only develop a state of burnout if she persists in ascribing high value to unattainable professional goals. Goal value is associated with professional engagement. Jesus (1996) investigated the influence of a series of motivational variables on teacher engagement and, among the variables considered, goal value accounted for the greatest amount of variance in professional engagement.

For example, a teacher who perceives her lack of success in maintaining positive interpersonal relations with her students and control of the classroom situation may attribute these failures to insufficient personal ability. Personal inability is an internal, stable and uncontrollable factor and, according to the learned helplessness model, the teacher may develop a generalised expectancy of inability to manage classroom situations - an expectancy of failure and helplessness. Regardless of how much-or how little-personal effort she expends, the teacher anticipates the same results

(C) International Association for Applied Psychology, 2005.
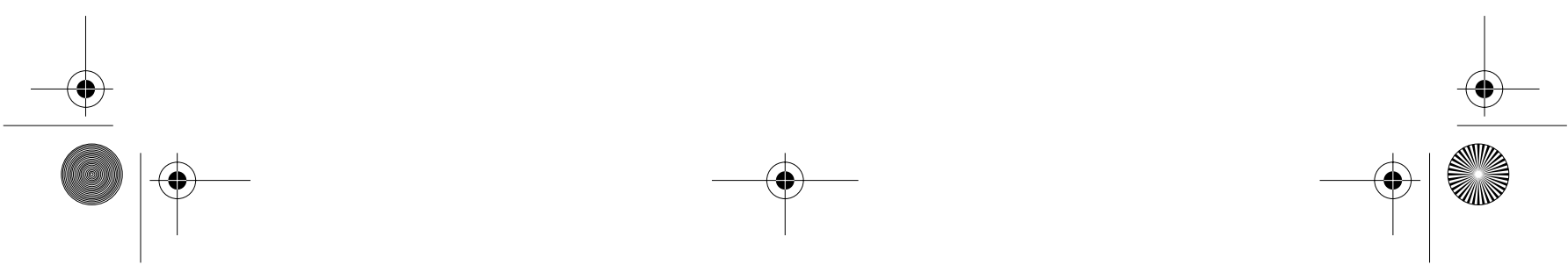


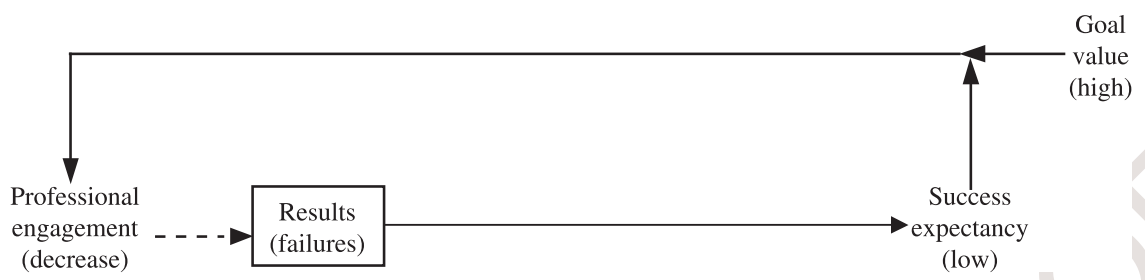

FIGURE 2 Teacher motivation predicted by the motivational discrepancy model

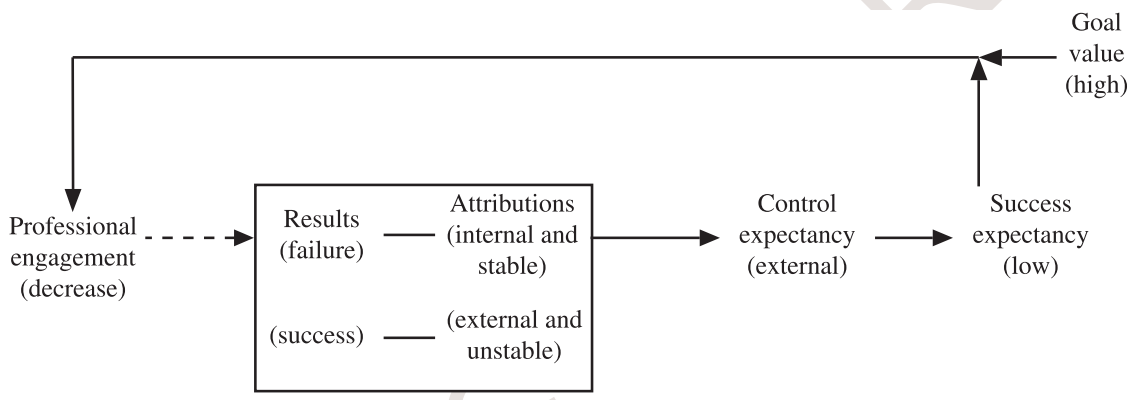

FIGURE 3 Integrated learned helplessness and motivational discrepancy models of teacher motivation

in her relationship with the students. The motivational discrepancy model would indicate that this situation turns stressful only if the teacher persists in valuing her relation with the students in spite of the low expectancy of success.

In this manner, the value of professional goals is fundamental for teacher performance, but it is a double-edged sword that may lead to reduced professional engagement if highly valued goals are not attained (see Figure 2).

The motivational discrepancy model, however, does not explain how the obtained results influence the expectations of the teacher. In addition, the failure to achieve a goal does not automatically imply a reduction in success expectancy. Reduced expectancy of success only occurs when failure is attributed to stable causes (as in the case of perceived lack of personal competence), and not when the failure is attributed to unstable causes-for instance the amount of effort exerted. In fact, failure attributions to unstable effort can lead to improved future effort and increased engagement.

Considering the foregoing, the integration of the two models can provide a more global and complete vision of the phenomenon of teacher motivation (see Figure 3).

(C) International Association for Applied Psychology, 2005.
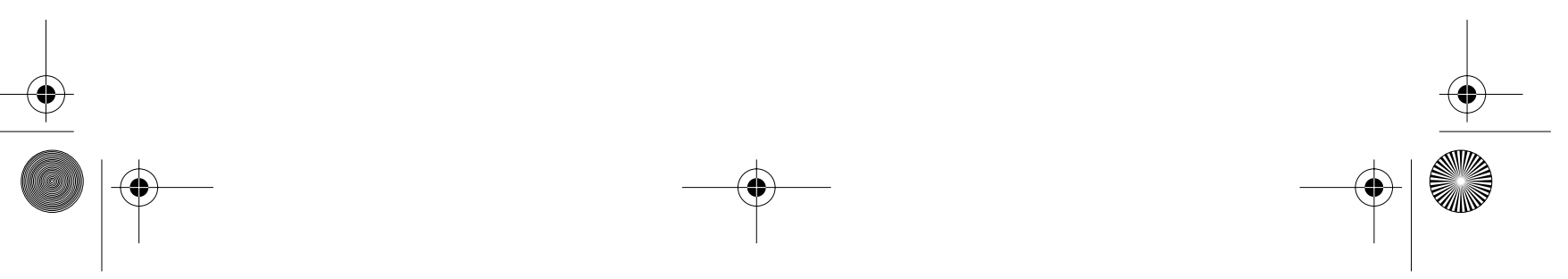


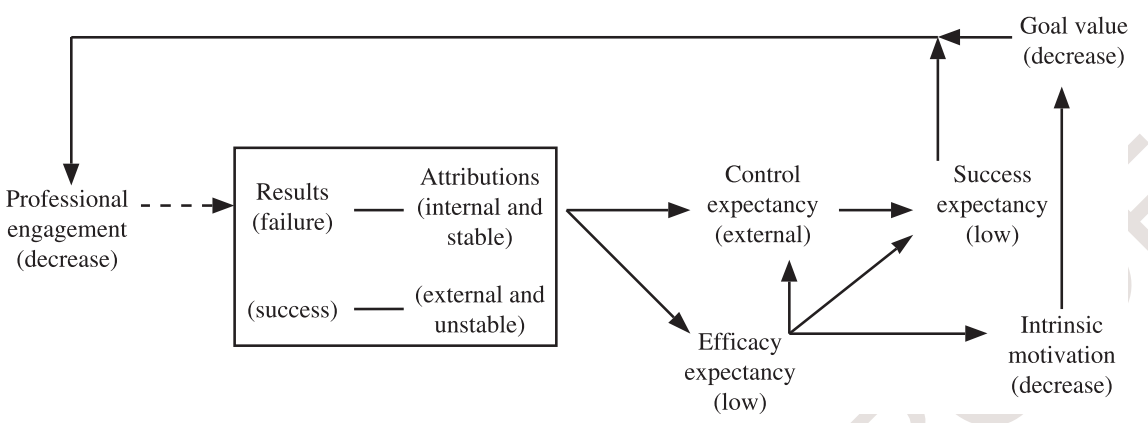

FIGURE 4 The integrated cognitive-motivational model for the study of teachers' professional motivation

Although more comprehensive, the model presented in Figure 3 offers no explanation, and no intervention strategy, as to how goal value can be altered given the teacher's professional results. Such an intervention leading to altered goal value is fundamental to the prevention of a permanent cycle of professional stress.

As an attempt to respond to this question, Figure 4 presents a still more comprehensive model, integrating variables proposed by other cognitive theories of motivation: self-efficacy theory (Bandura, 1977) and intrinsic motivation theory (Deci, 1975; Deci \& Ryan, 1985).

In the model presented in Figure 4, a teacher's self-efficacy results from patterns of the teacher's attributions. If a teacher makes internal and stable attributions (e.g. lack of capacity or competency) to explain perceived failure, low expectancy of personal efficacy will result. In the same way, if a teacher attributes success to external and unstable variables (e.g. good luck), it is likely that personal efficacy will remain unaffected.

According to Bandura, efficacy beliefs form the basis for performance expectations, so that the teacher who considers herself more competent tends to perceive greater control over the teaching/learning process. For example, it is assumed that the stronger a teacher's belief that she possesses good interpersonal skills, the greater her expectations of control over students' classroom behaviour.

Both expectancy of control of results as well as efficacy will influence success expectancy. In fact, success expectancy synthesises the effects of efficacy and control of results. In addition, efficacy expectations are the basis for teachers' intrinsic motivation since innate motives are directly linked to the perception of personal competence. Intrinsic motivation of the teacher also has roots in self-determination or motivational orientation for the teaching profession: the greater the personal desire to continue in the teaching profession, the greater the intrinsic motivation (Jesus, 1996; Nuttin, 1980, 1984).

(C) International Association for Applied Psychology, 2005.
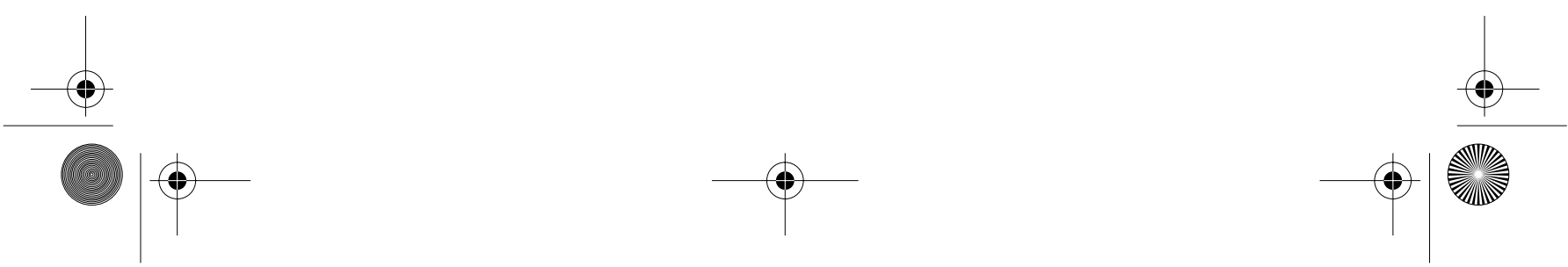
Finally, the intrinsically motivated teacher undertakes and completes professional tasks for their inherent value, as an end in itself. A teacher's intrinsic motivation, therefore, appears to influence the value ascribed to the situated goals in the teaching/learning process.

The model presented in Figure 4 permits an understanding of the situation in which a teacher decreases her professional effort, and simultaneously reduces her level of stress. This can occur by virtue of a decrease in the subjective value of teaching activities. The teacher perceives teaching as the source of her stress because she feels incapable of becoming a successful teacher. In this sense, the value of goals constitutes a basic determinant of both performance variance and level of professional stress.

Once again, consider the example of the new teacher. At the onset of her career she strives in her professional activities (high effort) and considers it of great importance to establish a positive and respectful relationship with her students (high goal value). In her classes, however, student behaviour is disruptive (goal failure). The teacher attributes this result to her lack of the personal qualities required to create good interpersonal relations in the classroom (internal and stable attributions). She begins to believe that she is incapable of establishing a good relationship with the students (low expectancy of personal efficacy) and concludes that factors other than her own behaviour determine student behaviour (expectancy of external control of results). This last step forms the foundation for her helplessness - the belief that, whether she exerts great effort, little effort or no effort at all, the results will be the same (low expectancy of success).

Following another scenario, low efficacy expectancy can lead to reduced intrinsic motivation and, therefore, to reduced goal value of professional activities. Following this scenario to its logical end, intrinsic motivation rebounds, as does the perceived goal value of teaching activity. Consequently, teacher effort improves, increasing the probability of success in the classroom.

The integration of these cognitive-motivational variables into the general model presented in Figure 4 may therefore help to explain teachers' lack of motivation, and may overcome some of the gaps and inadequacies of predictions made from isolated, antecedent models.

\section{TESTING THE INTEGRATIVE MODEL}

\section{Hypothesis and Methods}

Since the model proposes a relation of successive influence among its proposed variables, it can be analysed in a way that accounts for the variance of one variable as it influences each other variable in the proposed sequence. Such an analysis will allow predictions of the implications that may result from the implementation of more global intervention

(C) International Association for Applied Psychology, 2005.
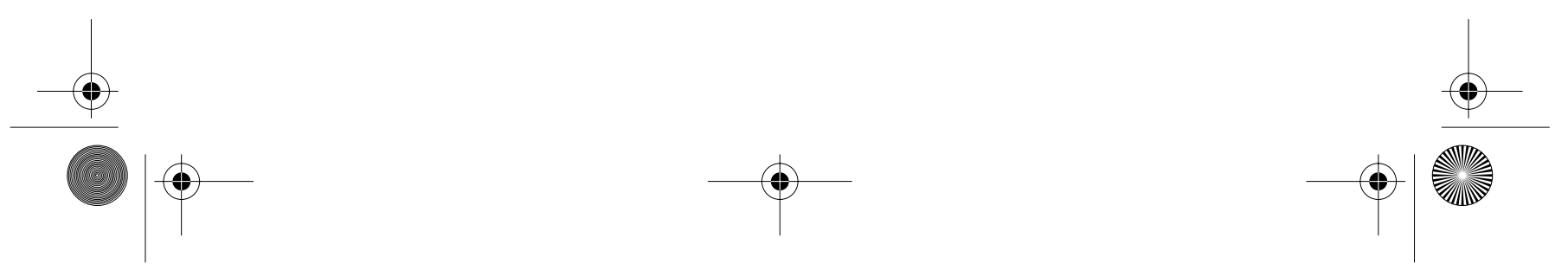
programs that can be used in teacher education programs, in order to improve teacher engagement.

Teacher professional engagement constitutes the best index of teacher motivation. Level of engagement has strong implications not only for professional success and the quality of teaching, but also for the implementation of educational reforms and the motivation of the students themselves. Professional engagement, therefore, is the ultimate endogenous variable specified in the model. All other variables in the model will be analysed as to their potential for predicting or explaining professional engagement.

The proposed model constitutes a global hypothesis that will be tested in this investigation. In addition, several specific hypotheses can be derived from the sequential relations stipulated in the model. For each endogenous variable in the model, a hypothesis is presented that stipulates the other variables that are expected to have a significant, positive and direct effect on it: (a) Professional engagement is positively influenced by goal value and by the expectancy of success; (b) Goal value is influenced by intrinsic motivation; (c) Intrinsic motivation is influenced by efficacy expectations; (d) Success expectancy is influenced by efficacy expectancy and by the expectancy of control of results; (e) Expectancy of control of results is influenced by efficacy expectancy, external and unstable failure attributions, and internal and stable success attributions; (f) Efficacy expectancy is influenced by external and unstable attributions for failure, and internal and stable attributions for success.

The integrated model presented is recursive, that is, the variables are hierarchically sequenced, and no variable that is hypothesised as the cause of a later variable is ever the effect of another subsequent variable. The causal flow is conceived as unidirectional. In addition, the proposed causal relationships are based on theory. The model is therefore subject to examination by path analysis (Vogt, 1993).

A path analysis is undertaken by calculating the strength of causal relations among the variables in the model, given the model's previously specified theoretical predictions. This multivariate procedure provides a tool for examining the level of empirical support for the proposed causal assumptions in a system of relations among the variables that constitute the model (Grady, 1989). Path analysis, in relation to multiple regression, has the advantage of permitting the calculation, not only of the direct effects of independent variables, but also the indirect effects on the exogenous variables (Vogt, 1993).

\section{Instruments}

An original self-report instrument was developed to examine the model. Scale construction and item selection were based on the theoretical meaning

(C) International Association for Applied Psychology, 2005.
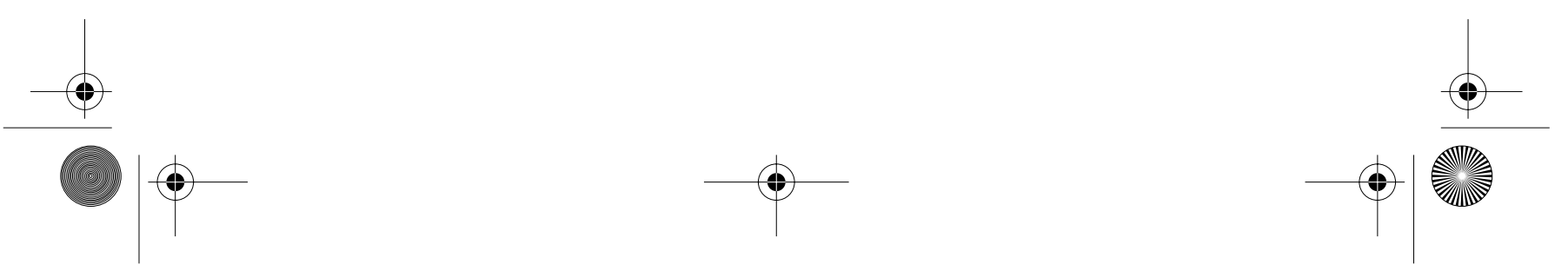
of the variables, the intended population of teachers, and the existence of scales previously tested and adapted to local culture (Tapia, 1992).

Scale items were initially selected from an extensive catalogue of previously tested, teacher-specific questions. Content validity of the scales was supported by selecting the items that best described and evaluated the variables being analysed.

A pilot study of the instrument's characteristics was then undertaken with a sample of Portuguese teachers. Items yielding a significant correlation with the Scale of Social Desirability (Reynolds, 1982) were eliminated following the recommendation of Palenzuela, Prieto, Barros, and Almeida (1994). In addition, items yielding a corrected item-to-scale correlation lower than .30 were eliminated (Golden, Sawick \& Franzen, 1984; Reckase, 1984).

Professional Engagement was measured with an 11-item, seven-point summative scale, anchored at the extremes from Never to Always. Engagement was operationalised to include participation in extra-curricular activities, encouraging and praising students, systematic course improvement, efforts at class preparation, availability to the students outside of class (both for questions and collaboration in projects) and, attempts to diversify teaching strategies.

Goal Value and Success Expectancies were each measured on five-point summative scales anchored at the extremes from A Little to A Lot. The stem for the Goal Value scale was, "As a teacher, it is important to me ..." followed by seven items, such as, "that the students learn", "to have a good relationship with the students", and "to help the students". The stem for the Success Expectancy scale was, "As a teacher I expect... ", followed by the same items in the Goal Value scale.

Seven-point summative scales, anchored from Disagree to Agree, were employed to measure Intrinsic Motivation (four items; for instance "teaching increases my self-esteem", and "teaching contributes to my personal development"), Efficacy Expectancy (six items; as examples "when I really try, I tend to succeed even with the students who have more difficulty", and "if a student is unable to do a determined task, I am able to evaluate up to which point the material in question surpasses the reasonable level of difficulty"), Control of Results Expectancy (eight items; namely, "what happens in my classes depends on my behaviour", and "I have no influence over students motivation"), Success and Failure Attributions (five items each; as examples, "my personal qualities and professional competence", and "working conditions in the schools"). The stems to assess attributions were "my successes in teaching is because ...", and "my failures in teaching is because ...".

In a previous study (Jesus, 1996), all the scales yielded internal consistency coefficients of $\alpha>.70$, except the scale to assess Success Attributions (Locus) with an alpha of .65, indicating adequate reliability (Pettegrew \& Wolf, 1982). The alpha coefficients, means and standard deviations are presented in Table 2.

(C) International Association for Applied Psychology, 2005.
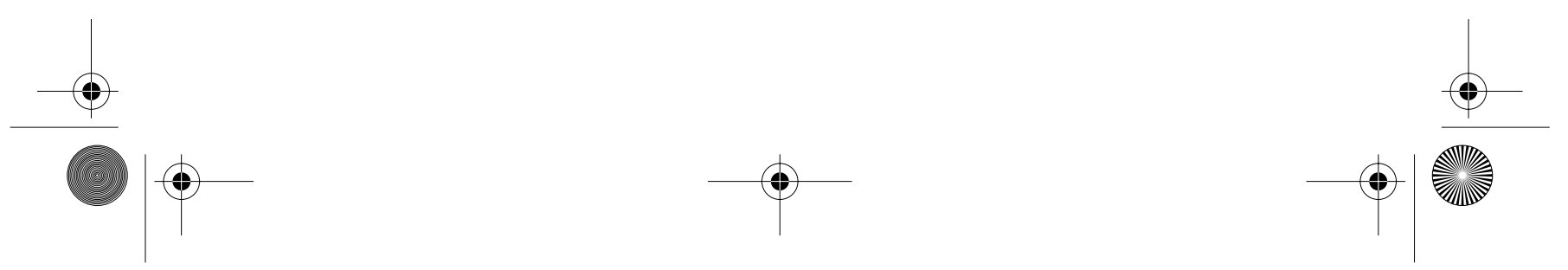


\section{Participants and Procedure}

Elementary and secondary-level teachers in Portugal cooperated in the study $(N=272)$. Missing data forced the removal of 14 teachers $(5.1 \%)$ from the sample. The remaining 258 teachers were between the ages of 22 and 55 (average age $=29.2$ years) with teaching experience ranging from 1 to 30 years (average $=4.6$ years). The sample was predominantly female $(78 \%)$, and included more teachers of language and literature $(N=179 ; 69.4 \%)$ than from the sciences $(N=79 ; 30.6 \%)$.

The study instrument was administered in groups, at the onset of a short course dealing with psychology and educational sciences that was part of a program of continuing teacher education. An investigator was present in order to provide instructions and respond to questions.

\section{RESULTS AND DISCUSSION}

Table 1 presents the results of the first step in the analysis, the multiple regression of the set of predictor variables on Professional Engagement. The full model yielded a value of $R^{2}=.295$. Only the coefficient associated with Goal Value yielded a significant influence over Professional Engagement. This tends to support the development of an integrated model in which the other variables, while not exercising a direct influence, may exert an indirect influence over Professional Engagement.

This being the case, the next step is to evaluate the structural relations among the variables and the paths that emerge, in order to see if they support the theoretical model. In order to accomplish this, the standardised regression coefficients $(\beta)$ of the model variables are calculated as these follow the proposed sequence. In addition, the variance of each endogenous variable that is explained by other variables assumed to contribute to that variance $\left(R^{2}\right)$ is calculated by means of successive multiple regression equations.

Table 2 gives the standardised regression coefficients and the variance of the endogenous variables of the hypothetical model as described above. Vertical columns report a series of separate regressions, with predictors at the left and dependent variables identified at the top. Table 2 only presents the regressions obtained between variables in each step of the model, and not all the possible relations. Nearly all of the relations proposed by the integrated model reveal significance. One exception was the coefficients obtained for the relations between attributions and expectancies. They yielded results not predicted by the model. Table 2 reveals that, although stable Success and Failure Attributions (endogenous variables number 2 and 4) contribute significantly to explain the variance of Control Expectancy, neither the locus nor the stability dimension of these attributions contributes

(C) International Association for Applied Psychology, 2005.
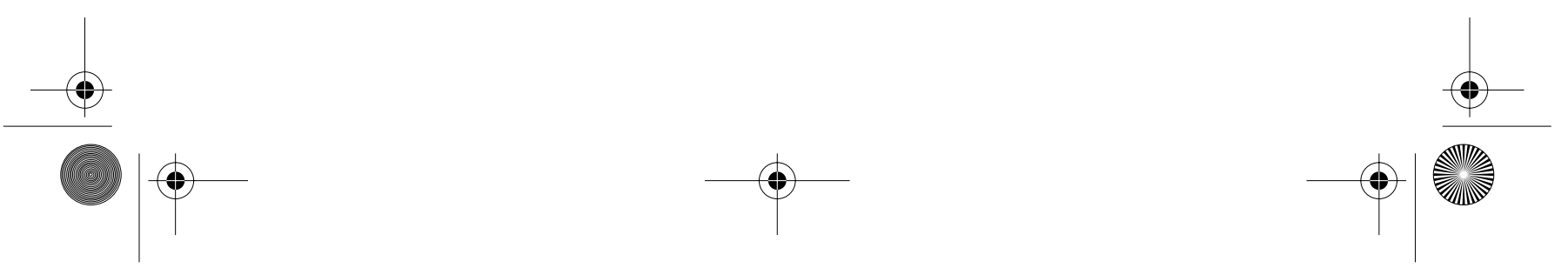

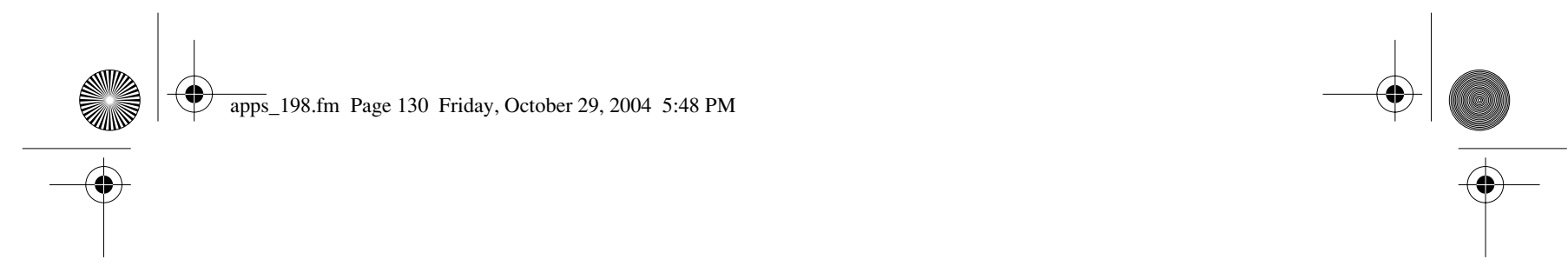

SAUL NEVES DE JESUS AND WILLY LENS

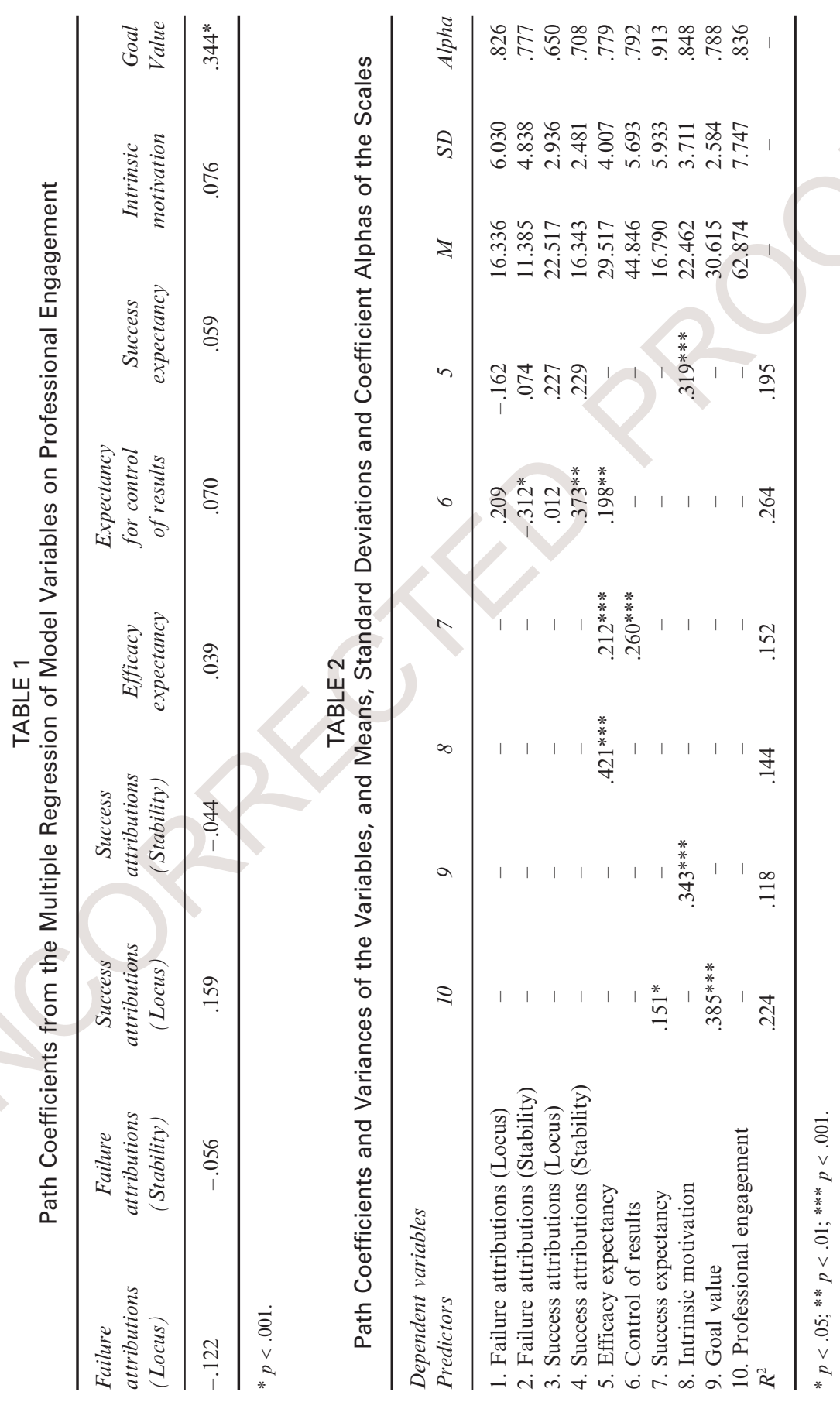

(C) International Association for Applied Psychology, 2005.
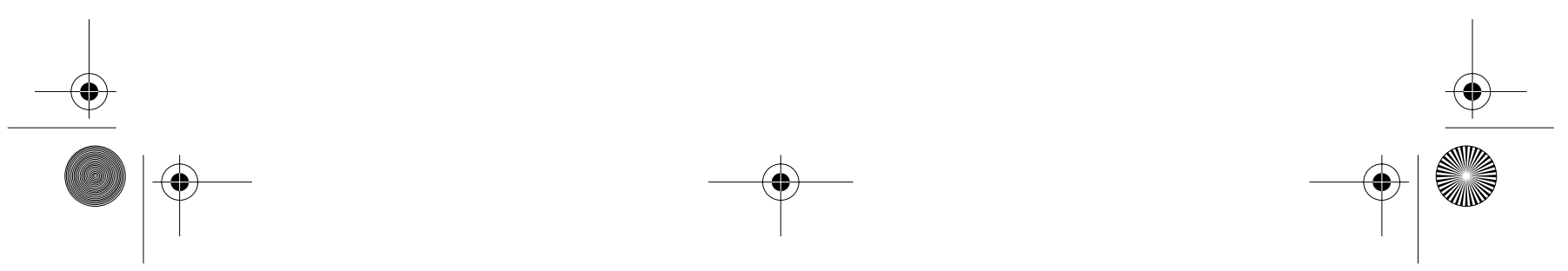


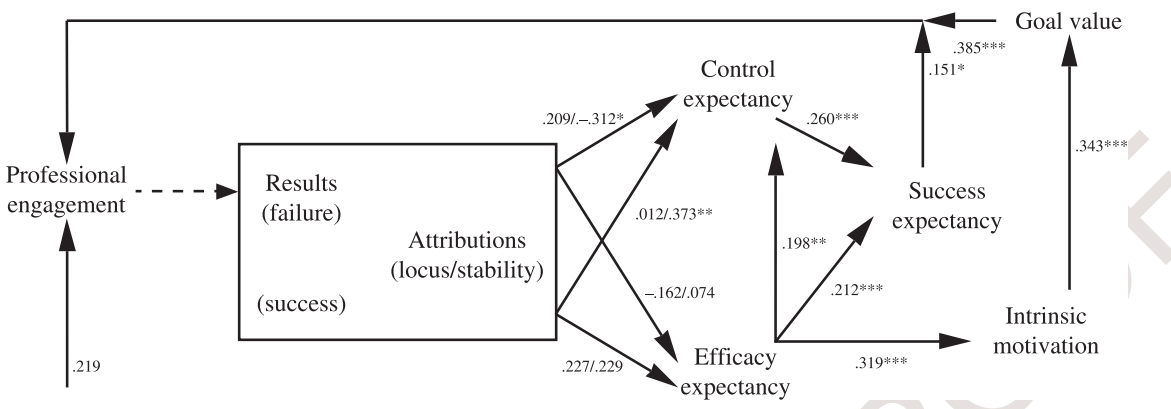

FIGURE 5 Path diagram of the proposed causal model

to explain Efficacy variance. These relations will require further research. Still, in general the results presented in Table 2 provide strong support for the proposed model.

Figure 5 presents the hypothetical or restricted model, with standard regression coefficients and the coefficient of alienation of the model. The coefficient of alienation of the model is the same as the product of the coefficients of alienation of each one of the internal variables (that is, the common variance not explained by the variables), and reveals the suitability of the model to explain the obtained results (Haase, 1994; Joreskog \& Sorbom, 1993). This coefficient is represented by an arrow from outside the model pointing to the last internal variable.

The coefficient of alienation is almost null (.219), indicating that the model explains much $(78.1 \%)$ of the common variance of the results obtained from the endogenous variables.

A Chi-square test that takes into account the number of subjects, number of paths and the coefficient of alienation (Haase, 1994; Joreskog \& Sorbom, 1993) verified the significance of the common variance explained by the $\operatorname{model}\left(X_{(14)}^{2}=570.96 ; p<.001\right)$. We can conclude that the proposed model finds support in the obtained results.

In sum, this study proposed the integration of cognitive-motivational constructs from diverse theoretical perspectives into a concise causal model. The model provided a reasonable explanation for teacher motivation when professional engagement was considered the primary indicator of that motivation. In addition, the study offers empirical support for cognitivemotivational intervention strategies in pre-service and in-service teacher education. Such strategies, according to the model, should be powerful tools in generally improving teacher motivation.

Further study of the model should focus on the relations of attributions with efficacy and control of result expectancies. The current study failed to

(C) International Association for Applied Psychology, 2005.
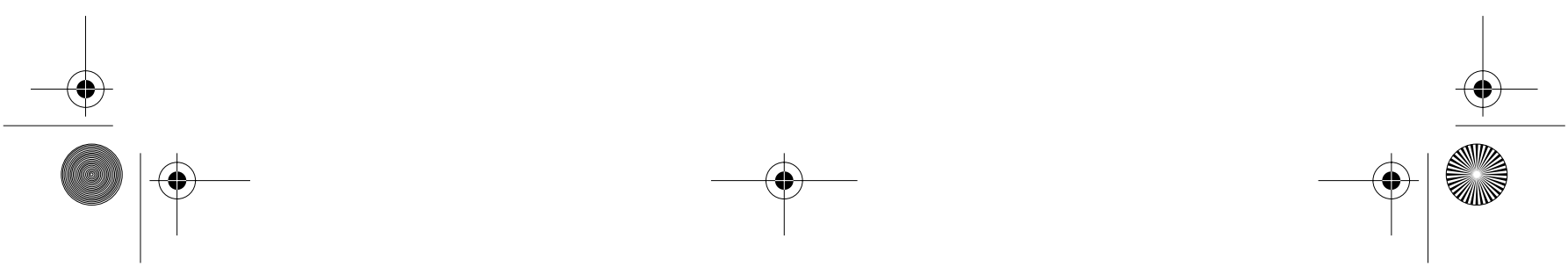
support the model's causal predictions in this regard. In addition, future studies should attempt to establish greater ecological validity of the model. This could be accomplished by including observational data on professional engagement.

\section{REFERENCES}

Abramson, L., Seligman, M., \& Teasdale, J. (1978). Learned helplessness in humans: Critique and reformulation. Journal of Abnormal Psychology, 87, 49-74.

Alvarez, C., Blanco, J., Aguado, M., Ruíz, A., Cabaco, A., Sánchez, T., Alonso, C., \& Bernabé, J. (1993). Revisión teórica del burnout o desgaste profesional en trabajadores de la docencia [Theoretical review of burnout: Professional stress of those working in teaching]. Caesura, 2(2), 47-65.

Bandura, A. (1977). Self-efficacy: Toward a unifying theory of behavioral change. Psychological Review, 84, 191-215.

Barros, J., Barros, A., \& Neto, F. (1993). Psicologia do controlo pessoal. Aplicações educacionais, clínicas e sociais [The psychology of personal control: Educational, clinical and social applications]. Braga, Portugal: Department of Education, University of Minho.

Deci, E. (1975). Intrinsic motivation. New York: Plenum Press.

Deci, E.L., \& Ryan, R.M. (1985). Intrinsic motivation and self-determination in human behavior. New York: Plenum Press.

Esteve, J. (1992). O mal-estar docente [Teacher stress]. Lisbon: Escher.

Ford, M. (1992). Motivating humans. Goals, emotions, and personal agency beliefs. London: Sage Publications.

Golden, C., Sawick, R., \& Franzen, M. (1984). Test construction. In G. Goldstein \& M. Herson (Eds.), Handbook of psychological assessment (pp. 19-37). New York: Pergamon Press.

Grady, T. (1989). Determinants of career commitment and turnover behavior. Journal of Vocational Education Research, 14(2), 1-21.

Haase, R. (1994). An introduction to path analysis and structural equation modeling. Unpublished manuscript.

Jesus, S. (1995). Análise da motivação para a profissão docente segundo o modelo da discrepância motivacional. Um estudo preliminar. [Analysis of motivation for the teaching profession according to the motivational discrepancy model: Preliminary study]. Revista Portuguesa de Educação, 8, 163-180.

Jesus, S. (1996). A motivação para a profissão docente [Motivation for the teaching profession]. Aveiro, Portugal: Estante Editora.

Jesus, S.N., \& Conboy, J. (2001). A stress management course to prevent teacher distress. International Journal of Educational Management, 3, 131-137.

Joreskog, K., \& Sorbom, D. (1993). Testing structural equation models. In K.A. Bollen \& J.S. Long (Eds.), Testing structural equation models. Newbury Park, CA: Sage Publications.

Kyriacou, C. (1987). Teacher stress and burnout: An international review. Educational Research, 29, 146-152.

(C) International Association for Applied Psychology, 2005.
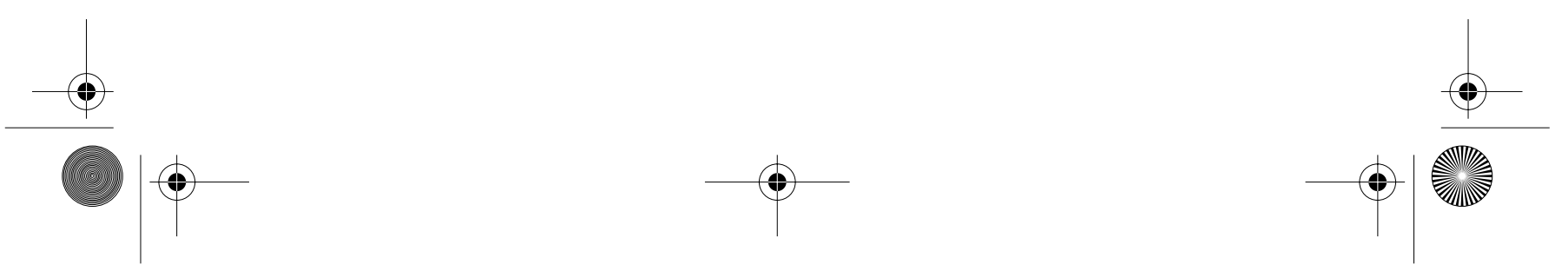
Lens, W., \& Decruyenaere, M. (1991). Motivation and demotivation in secondary education: Student characteristics. Learning and Instruction, 1, 145-159.

Lens, W., \& Jesus, S.N. (1999). A psychosocial interpretation of teacher stress and burnout. In R. Vandenberghe \& A.M. Huberman (Eds.), Understanding and preventing teacher burnout (pp. 192-201). Cambridge: Cambridge University Press.

Martínez-Abascal, M. (1991). El malestar docente explicado a través del modelo reformulado de desamparo aprendido [Teacher stress explained by the reformulated learned helplessness model]. Unpublished doctoral dissertation, University of Ilhas Baleares, Palma de Maiorca.

Miller, I. \& Norman, W. (1979). Learned helplessness in humans: A review and attribution-theory model. Psychological Bulletin, 86, 93-118.

Mowday, R., Koberg, C., \& McArthur, A. (1984). The psychology of the withdrawal process: A cross-validation of Mobley's intermediate linkages model of turnover in two samples. Academy of Management Journal, 27, 79-94.

Nuttin, J. (1980). Théorie de la motivation humaine. Du besoin au projet d'action [Theory of human motivation: From need to action project]. Paris: Presses Universitaires de France.

Nuttin, J. (1984). Motivation, planning, and action: A relational theory of behavior dynamics. Leuven \& Hillsdale, NJ: Leuven University Press \& Erlbaum.

Palenzuela, D. (1988). Refining the theory and measurement of expectancy of internal vs. external control of reinforcement. Personality and Individual Differences, 9(3), 607-629.

Palenzuela, D., Prieto, G., Barros, A., \& Almeida, L. (1994). Evaluación de las expectativas generalizadas de control: Versión revisada [Evaluation of the generalised expectancy of control: Revised version]. In L. Almeida (Ed.), Avaliação psicológica: Formas e contextos (pp. 281-294). Braga, Portugal: University of Minho.

Pettegrew, L., \& Wolf, G. (1982). Validating measures of teacher stress. American Educational Research Journal, 19, 373-396.

Pithers, R.T., \& Fogarty, G.J. (1995). Occupational stress among vocational teachers. British Journal of Educational Psychology, 65, 3-14.

Porter, L., \& Steers, R. (1973). Organizational work and personal factors in employee turnover and absenteeism. Psychological Bulletin, 80, 151-176.

Prick, L. (1989). Satisfaction and stress among teachers. International Journal of Educational Research, 13, 363-377.

Reckase, M. (1984). Scaling techniques. In G. Goldstein \& M. Herson (Eds.), Handbook of psychological assessment (pp. 38-53). New York: Pergamon Press.

Reynolds, W. (1982). Development of reliable and valid short forms of the Marlowe-Crowne Social Desirability Scale. Journal of Clinical Psychology, 38, $119-124$

Rotter, J. (1990). Internal versus external control of reinforcement: A case history of a variable. American Psychologist, 45, 489-493.

Stephenson, D. (1990). Affective consequences of teachers' psychological investment. Journal of Educational Research, 84(1), 53-57.

Tapia, J. (1992). Evaluación de la motivación [Motivational assessment]. In R. Fernández-Ballesteros (Ed.), Introducción a la Evaluación Psicológica

(C) International Association for Applied Psychology, 2005.
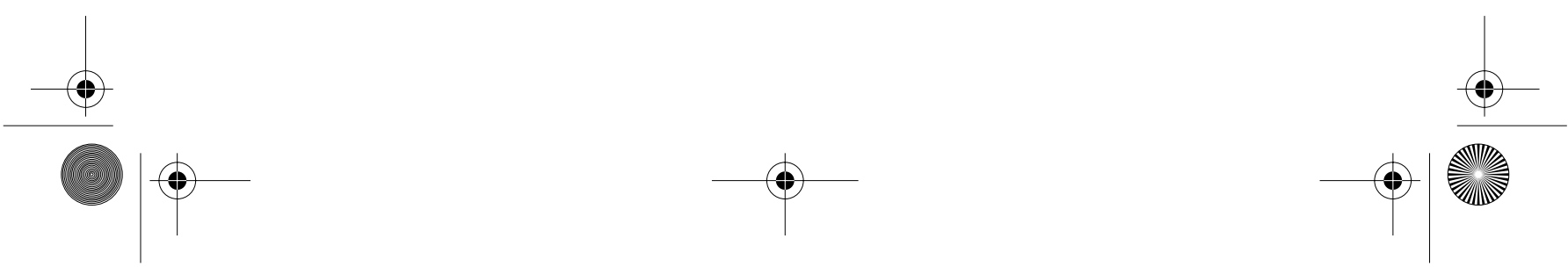


\section{SAUL NEVES DE JESUS AND WILLY LENS}

[Introduction to psychological assessment] (vol. 2, pp. 157-203). Madrid: Editiones Pirámide.

Vogt, W. (1993). Dictionary of statistics and methodology. Newbury Park: Sage Publications.

Weiner, B. (1992). Human motivation: Metaphors, theories, and research. Newbury Park, CA: Sage Publications.

(C) International Association for Applied Psychology, 2005.

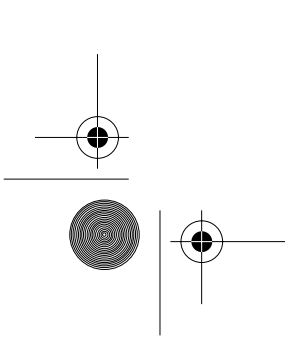

